\title{
Broken Passage to the Summit: Nayancheng's Botched Mission in the White Lotus War
}

\author{
Yingcong Dai
}

In ruling an extensive empire in pre-modern times, a monarch often delegated his authority to his representatives. In China, this practice reached its apogee during the Qing dynasty (1644-1912) when the Manchu rulers developed a sophisticated system of appointing both provincial governors and governors-general for its regular provinces and designated administrative commissioners for its protectorates. In addition to territorial administrators, the political centre of an empire also detailed special commissioners, from time to time, to inspect its territories and to accomplish special tasks, civil or military, which served as another means to cement the bonds between the centre and the provinces. During the Qing dynasty, special commissioners sent by the imperial court were often granted the ad hoc title, 'Qinchai Dachen' or 'Special Imperial Commissioner.' For some commissioners who were political upstarts, a successful mission could serve as a steppingstone to more prominent positions because the achievement, as well as the experience, enhanced their credentials. But a failed mission could well lead to disgrace, punishment, or worse.

This chapter sheds light on the story of an imperial commissioner in Qing China. In 1799, a Manchu aristocrat, Nayancheng (1764-1833), was appointed as a Special Imperial Commissioner to supervise the suppression campaign against a sectarian rebellion, the White Lotus Rebellion (1796-1805). Not only was he expected to inject new energy into the enervated campaign and promote the reform at the warfront, but it was also anticipated that he would prove his own worthiness so that he could be named to lead the Grand Council, the Qing monarch's key advisory body. Nevertheless, Nayancheng's mission ended in failure, with severe consequences for him as well as for the central government. Humiliated and stripped of almost all his numerous titles, Nayancheng fell so precipitously that he had to strive the rest of his life to re-prove himself but received only more denunciation and disgrace. At the same time, Nayancheng's downfall doomed the practice of the monarch relying on a single leading aide, which was a contributing factor to the reforms of the Qing central authorities during the transition from the Qianlong period (1736-1795) to the Jiaqing period (1796-1820). 
Nayancheng's failed mission occurred at a critical moment for the Qing. At the beginning of 1796, the Qianlong emperor abdicated the throne in favour of his son, the Jiaqing emperor, but continued ruling for three more years until he died at the beginning of 1799. While Qianlong's sixty-year reign was one of the golden ages in Chinese history, the successional transition was sullied by two sizeable rebellions. In 1795, the last year of Qianlong's reign, the Miao ethnic people in the southwest revolted, protesting Chinese immigrants' encroachment in their home areas. The intense fighting did not end until 1797. Several months after the start of the Miao Rebellion and several days after the new Jiaqing emperor's enthronement, the White Lotus Rebellion erupted. ${ }^{1}$ Within the year of 1796, more than a dozen uprisings occurred in western Hubei, southern Shaanxi, and north-eastern Sichuan. Taking advantage of the rebels' vague political agenda, loose organisation, and poor military strategy and tactics, the Qing forces destroyed most of their strongholds by early 1797, and forced the rebels of Xiangyang in northern Hubei, one of the bastions of the sectarian movement, to leave Hubei for Sichuan. However, when they reached northern Sichuan in the summer of 1797 , the insurgents of the two provinces failed to merge. Subsequently, about a dozen rebel groups, each numbering hundreds or thousands people, wandered and conducted guerrilla warfare in the border regions between Shaanxi and Sichuan, occasionally infiltrating into north-western Hubei and south-eastern Gansu. ${ }^{2}$

Although the rebellion itself did not pose a grave challenge to the Qing state, the suppression campaign had been lethargic and ineffective, failing to finish off the already disarrayed insurgents year after year. By the beginning of 1799 when Qianlong died, the campaign had hit an impasse. The bungled campaign revealed a number of serious problems in the empire's political and military

1 First appearing in the twelfth century, the White Lotus teaching evolved into an amalgam of Buddhism, Taoism, Confucianism, Manichaeism, and other teachings with distinctive millenarian characteristics. Although numerous sects had sprung from it, both the state and some sectarian members used 'White Lotus' as an umbrella name to refer to various sects. In the 179os, the Qing state's pre-emptive actions against some of these sects prompted their leaders to plan an uprising. Meanwhile, social stresses caused by overpopulation and Qing crackdowns on salt-smuggling and coin-counterfeiting radicalised many in central China.

2 I try to provide a comprehensive picture of the rebellion, the suppression campaign, and the high politics intertwined with the war in a book-length manuscript, "The White Lotus War: Late Imperial China in Crisis." Some of my findings have appeared in 'Civilians Go into Battle: Hired Militias in the White Lotus War, 1796-1805', Asia Major, Third series, Volume XXII, no. 2 (2009), $145^{-178 . ~}$ 
structures. The Qing central authorities failed to exercise control over the field commanders and provincial viceroys, many of whom had exhibited an inclination to stall the campaign from the beginning and boldly misappropriated the war funds which had been amply supplied by the central government.

The Qing state did attempt to reverse this situation. More particularly, after his father's death, the Jiaqing emperor made strenuous efforts to get the derailed suppression campaign back on track. But at first the new emperor had to assert his own authority in the imperial court. Several days after Qianlong's death, Jiaqing purged Hešen (1750-1799), the leading grand councillor and Qianlong's primary aide, and Fuchang'an, Hešen's right arm and vice-minister of revenue. Being a skilful sycophant as well as a capable administrator, Hešen had won Qianlong's unreserved trust, and managed to dominate the imperial court for more than two decades beginning in the mid-1770s. Capitalising on his power, Hešen had amassed enormous property holdings by pressing for and accepting bribes, which earned him a reputation as the most corrupt person in the empire. To be sure, Hešen was not the first such figure in Qianlong's court. From the start of the Qianlong reign, the emperor had deliberately fostered one powerful courtier after another, allowing him tremendous authority over his bureaucracy. Typically, this person held the leading position on the Grand Council. When the Grand Council was created by Qianlong's father, the Yongzheng emperor (r. 1723-1735), it was no more than a temporary office to process military correspondence between the court and the frontline of the war against the Zunghar Mongols in the far northwest. Not until the early Qianlong period did the council become a permanent advisory body to aid the monarch in decision-making on critical issues. Meanwhile, Qianlong was inclined to rely on one leading grand councillor, making him a de facto chancellor or prime minister. ${ }^{3}$

The first such figure was Necin (d. 1749), a political upstart from a prominent Manchu family. ${ }^{4}$ The young Necin was appointed to the Grand Council as a junior member by the Yongzheng emperor a few years before the latter's

3 The most important work on the Grand Council remains that by Beatrice S. Bartlett, Monarchs and Ministers: The Grand Council in Mid-Ch'ing China, 1723-1820 (Berkeley, 1991). On the leader of the Grand Council, see 173-177.

4 Necin's great grandfather, Eidu, one of the early followers of Nurhaci, was instrumental in the founding of the Qing dynasty. Eidu's youngest son and Necin's grandfather, Ebilun, had been one of the regents to the Kangxi emperor (r. 1662-1722). On the family, see Evelyn S. Rawski, The Last Emperors: A Social History of Qing Imperial Institutions (Berkeley, 1998), 63-66, and Lai Hui-min, 'Qingdai de Niuhulu Shi yu Tatala Shi', in Lai Hui-min, Qingdai de Huangquan yu Shijia (Beijing, 2010), 177-208. 
sudden death. Under the new Qianlong emperor, Necin rose to power quickly. He was given many titles and the highest noble rank, the duke of the first grade. Most importantly, Necin became the leading member of the Grand Council. ${ }^{5}$ In 1748, when the first Jinchuan war on the north-western marches of Sichuan province against a Gyalrong tribe did not go well, Necin was sent to the front to supervise the war as the Grand Minister Commander (Jinglüe Dachen), the highest ad hoc military position. However, Necin failed to break the impasse. In late 1748, Qianlong called Necin back to the capital. In addition to dismissal, Qianlong ordered that Necin be escorted to the Jinchuan front and commit suicide in front of the armies. For this purpose, Qianlong sent Necin a dagger left by his grandfather, Ebilun. ${ }^{6}$

After Necin was called back, Qianlong appointed Fuheng (1719-1770), the younger brother of Qianlong's first empress and a junior grand councillor at the time, as the new Grand Minister Commander. ${ }^{7}$ To Fuheng's advantage, the belligerent Jinchuan chieftain had begun seeking a truce due to the exhaustion of his resources. In early 1749, Yue Zhongqi, a talented general who was familiar with the local conditions in the rugged Jinchuan area and had personal connections with the rebellious local chieftain, volunteered to go to the chieftain's headquarters and negotiate with him, producing the chieftain's surrender. The satisfactory conclusion of the war paved the way for Fuheng's ascendance as the chief grand councillor. Unlike Necin who had often behaved condescendingly, Fuheng was modest and circumspect. After having held the position for two decades, Fuheng went on to lead another frontier war in the late 1760 s against Myanmar. But this time, he failed to accomplish his task. In the inhospitable borderlands between China's Yunnan and north-eastern Myanmar, thousands of Qing troops died of disease, including Aligun, one of the deputy

5 On the concurrent positions of the grand councillors, see Bartlett, Monarchs and Ministers, 186-190. She holds that it was an indication of the expansion of the power of the Grand Council.

6 However, the war ended before his arrival. Necin was thus executed en route. Zhaolian, Xiaoting Zalu (Beijing, 1980), 14. On the first Jinchuan war, see Zhuang Jifa, Qing Gaozong Shiquan Wugong Yanjiu (Taipei, 1982), 116-128.

7 Fuheng was from the Fuca clan. His grandfather, Mishan, was the minister of revenue during the Kangxi reign. On the family, see Evelyn Rawsky, The Last Emperors, 86-87. R. Kent Guy notes the importance of military affairs in Fuheng's career. Guy, Qing Governors and Their Provinces: The Evolution of Territorial Administration in China 1644-1796 (Seattle, 2010), 131-132. 
commanders and the younger brother of Necin; Fuheng himself also fell ill and died in 1770 , shortly after his return to Beijing. ${ }^{8}$

After having experienced a period of crisis in the wake of Fuheng's death, and without a leading aide to lean on, Qianlong began directing his trust to Hešen, a low-ranking courtier at the time. Despite his dominance at the court, Hešen did not become the leading grand councillor until 1797, when the de jure number one grand councillor, Agūi (1717-1797) died. The son of a high-ranking court official, Aguii rose to prominence through a different path than that of Necin and Fuheng. Whereas Necin and Fuheng centred their entire careers on the imperial court, Agūi first built his reputation as an outstanding general through many wars on the frontiers and proved his capacity as a territorial administrator as well in the provinces before he was summoned back to the capital in the late 1770s. After he became the leading member of the Grand Council, Agūi was, however, unwilling to challenge Hešen's power, often taking on tasks in the provinces. ${ }^{9}$ Although the true nature of Agūi's relationship with Hešen remains a question, the general impression among officials was that the two were enemies. Therefore, Hešen's opponents rallied around Agūi, even though Agūi had never openly associated himself with any attempt to discredit Hešen.

Not surprisingly, the Jiaqing emperor's purge of Hešen generated a great deal of excitement in the court and throughout officialdom. Many took it as a signal of a shift in court culture, from one dominated by cronies to one open to the input of upright and farsighted officials. But this did not seem to be Jiaqing's intention. For him, the removal of Hešen was simply a prerequisite to asserting and exercising his own authority, as Qianlong's crony Hešen had been disrespectful to Jiaqing, which had long annoyed the young emperor. Like the Kangxi emperor who purged Oboi, his overbearing regent, soon after he took the reins of government in 1669, Jiaqing could not allow Hešen to stay where he had been once Qianlong passed away. Indeed, Jiaqing compared Hešen to Oboi of the Kangxi reign, Nian Gengyao of the Yongzheng reign, and Necin of the Qianlong period. Among the three, Jiaqing thought, however, that Hešen's case was most similar to that of Necin. In his likening of Hešen to Necin, Jiaqing repeatedly asserted that Hešen's gravest 'crime' was that he

8 On the Myanmar war, especially Fuheng's role in the war, see Yingcong Dai, 'A Disguised Defeat: The Myanmar Campaign of the Qing Dynasty', Modern Asian Studies 38, no. 1 (2004), $145^{-188 .}$

9 After having obtained a juren degree at the age of twenty-one, Agūi had served in the central government for a decade and became a secretary of the Grand Council. Starting with the first Jinchuan war, Agūi participated in and commanded numerous wars. 
had hindered the military operations at the front by delaying forwarding the reports from the front to the throne and was therefore responsible for the slow and unsatisfactory progress of the campaign. ${ }^{10} \mathrm{He}$ tried to justify his removal of Hešen as sanctioned by the precedent set by his father, by which the chief councillor could suffer capital punishment if he had hindered a military campaign from progressing to victory.

Nevertheless, there was no evidence to prove the accusation. Ironically, months earlier, the Qianlong emperor had lavishly praised Hešen and granted him the dukedom exactly for his able handling of military correspondence. ${ }^{11}$ Perhaps aware of the weakness of his case, Jiaqing wanted to move quickly. He ordered Hešen to commit suicide by hanging himself but reduced the penalty to Fuchang'an from beheading as proposed by court officials to imprisonment. He did not dismiss or punish Hešen's protégés either in the central bureaucracy or in the provinces. ${ }^{12}$ Jiaqing did not, however, condemn Hešen for dominating the Grand Council or usurping the power of the emperor, the man's most odious crime according to many people within and without officialdom. In other words, Jiaqing did not mean to reform the political centre. More specifically, Jiaqing did not intend, at this point, to alter Qianlong's practice of relying on a single chief grand councillor in managing critical state affairs. On the contrary, he tried to fill the void left by Hešen with a new leading grand councillor.

10 Da Qing Renzong Rui Huangdi Shilu (reprinted. Tokyo, 1937-1938; hereafter QSLJQ), 38/3a-b (number of juan/page number) and Jiaqing Chao Shangyu Dang (Guilin, 2008; hereafter JQCSYD), vol. 4, 16. Nian Gengyao had been the Yongzheng emperor's confidant, but he was not in the same position as Oboi and Necin; he was the governor-general of Sichuan when Yongzheng was enthroned. He was purged and ordered to commit suicide in 1726 when Yongzheng found him too overbearing.

11 Qianlongdi Qijuzhu (Guilin, 2002), vol. 42, 530-531. Bartlett has also doubted the validity of Jiaqing's accusation since there would have been little advantage for Hešen in withholding the correspondence from the campaign. Bartlett, Monarchs and Ministers, 235-236.

12 But Fuchang'an should be escorted to witness Hešen's suicide, as Jiaqing ordered. QSLJQ, 37/5ob-51b; 38/2b-5a; JQCSYD, vol. 4, 31-34. Neither did Jiaqing further punish Hešen's family after the man's death and the confiscation of most of his property, although some of Hešen's household managers were punished. One exception for Hešen's family was that Jiaqing repudiated Helin, Hešen's younger brother who died of illness in the Miao campaign in 1796, ordering the stripping of Helin's noble title, the removal of his tablet from the imperial ancestral temple, and the dismantling of his shrine in his home. QSLJQ, 38/5a-6a. On the limited scope of the purge, also see David S. Nivison, 'Ho-shen and His Accusers: Ideology and Political Behavior in the Eighteenth Century', in David S. Nivison and Arthur F. Wright, ed., Confucianism in Action (Stanford, 1959), 241. 
From Jiaqing's perspective, this new leading grand councillor should have been his own protégé, instead of a senior official from his father's reign, who had played a role as his mentor. Given that Agūi, even posthumously, had enjoyed the reputation of a leading rival of Hešen, Jiaqing was inclined to lean on either Agūi's associates or his relatives once he took power. Of Agūi's offspring, Nayancheng, his grandson, was the most hopeful to inherit Agūi's mantle. Two of Agūi's sons, including Nayancheng's father, Asida, had died, and Agūi's other son, Adisi, was mediocre (yet Adisi was appointed by Jiaqing as vice-minister of war). ${ }^{13}$ Therefore, while Jiaqing reshuffled both the inner court and the central bureaucracy in the wake of Hešen's death, filling key positions with people he trusted - in fact, several people appointed had close relationships with Agūi ${ }^{14}$ — he started to foster and promote Nayancheng.

Unlike many other youngsters of Manchu noble families in his day who ushered themselves into officialdom by taking advantage of their privileges as the ruling elites or purchasing degrees, Nayancheng earned his degrees by succeeding in the examinations at all levels. In 1789, at the age of twenty-five, he became a jinshi, the highest degree from the Civil Service Examinations. Having held a position for several years at the Hanlin Academy, in 1792, he was called to the Qianlong emperor's service at the Imperial Study (Nanshufang), the privy consultative body of the emperor. In the last few years of the Qianlong reign, Nayancheng served as one of Qianlong's diarists, recording the emperor's daily activities and instructions. In 1795, he started to accompany the grand councillors, Agūi, Hešen, and others, in discussions with the emperor on important issues. Shortly after Agūi died in the autumn of 1797, Nayancheng was placed on the Grand Council as a probationary member (Xingzou). ${ }^{15}$ Working directly

13 JQCSYD, vol. 4, 44.

14 Jiaqing appointed Songyun, a Mongol bannerman, to head the Ministry of Revenue, which had been controlled by Hešen and Fuchang'an for many years. Songyun used to be on the Grand Council, but took the position of amban in Tibet in 1794 in order to keep his distance from Hešen. For Sonyun's time and achievements in Lhasa, see Sabine Dabringhaus, Das Qing-Imperium als Vision und Wirklichkeit. Tibet in Laufbahn und Schriften des Song Yun (1752-1835) (Stuttgart, 1994). For the Ministry of Personnel, Jiaqing named Shulin, another Agūi associate but Hešen's enemy, as the head. Jiaqing also put his two brothers, Yongxing and Yongxuan, on the Grand Council and in charge of various departments in the central government. He called his teacher, Zhu Gui, back to the capital from the south, to become his chief advisor, and reinstated several grand councillors and grand secretariats who had taken leave.

15 The edict of the appointment cited his Hanlin Academy background, his intelligence, and the fact that he was Agūi's grandson. Jiaqingdi Qijuzhu (Guilin, 20o6; hereafter JQQJZ), vol. 3, 39 and 45. If not otherwise noted, information on Nayancheng's life and 
under Hešen, Nayancheng participated in processing the correspondence relating to the White Lotus war. ${ }^{16}$ In 1798 , he was appointed as vice-minister of works, and deputy supervisor of commercial revenue collection in Beijing (the supervisor was Hešen). Nayancheng's debut in the inner court might have been one of the reasons for Agūi to avoid involving himself in any form of opposition against the powerful Hešen. Furthermore, Hešen might well have played the role of a mentor to the young Nayancheng, for Nayancheng's appointment to the Grand Council would not have been possible had Hešen opposed it.

Hešen's fall did not affect Nayancheng's career adversely. Instead, his career took off. Being Agūi's grandson, and a jinshi (Nayancheng was, in fact, the third Manchu or Mongol bannerman on the Grand Council who had the degree), ${ }^{17}$ and with his several years' experience in the inner court, Nayancheng was an ideal candidate for the number one place on the Grand Council. ${ }^{18}$ In merely seven months, between February and September in 1799, the Jiaqing emperor appointed Nayancheng to numerous positions, in addition to naming him a full member of the Grand Council, which placed the thirty-five-year-old in a status comparable to that of the fallen Hešen. Like Hešen, Nayancheng came to be in charge of several critical functions and agencies of the central government, such as the Hanlin Academy, the Ministry of Revenue, the Ministry of Works, the Ministry of War, the Institute of Historiography, the editorial committee of the imperial 'Veritable Records', the internal revenue collection in the capital city, the palace maintenance office, and the Imperial Household Department. He was also granted the privilege of riding horses inside the Forbidden City, an indication of his lofty status. ${ }^{19}$ Like Hešen, Nayancheng was the leader of more

career below is taken from several biographies: Zhao Erxun, Qingshigao (Beijing, 1977), 11458-11463; Qingshi Liezhuan (Reprinted. Taipei, 1985), vol. 5, 3-18; Arthur W. Hummel, Eminent Chinese of the Ching Period (Washington D.C., 1944), 584-587; Zhuangao, No. 5686 (housed in the National Palace Museum, Taipei).

16 Along with several other grand councillors, Nayancheng was commended by Qianlong for his effective handling of the war correspondence after a leading rebel chief was captured in the autumn of 1798. Qianlongdi Qijuzhu, vol. 42, 530-531.

17 The other two were Yinjishan, who became grand councillor in 1748, and Menglin, who joined it in 1756. Bartlett, Monarchs and Ministers, 374.

18 Jiaqing later said of Nayancheng: 'Nayancheng is a grand councilor... and he is fair, and conversant with both Manchu and Chinese., Qinding Jiaoping Sansheng Xiefei Fanglüe (Reprinted. Taipei, 1970; hereafter cited as XFFL), 166/11b-12a (number of juan/page number).

19 He was first named as the president (Zhangyuan) of the Hanlin Academy on 12 February 1799 (JQCSYD, vol. 4, 13). Two weeks later, on 25 February, Nayancheng was appointed as the minister of works (Ibidem, vol. 4, 37). A few days later, he was given another title, the 
than one banner. ${ }^{20}$ Jiaqing had to take away some titles from Nayancheng, simply because he held too many of them concurrently. Compared with Hešen's relatively gradual ascent, Nayancheng's rise was meteoric.

As Jiaqing later admitted, he indeed had great expectations of Nayancheng and promoted him speedily for a purpose:

At the time when I took the reins of government and dealt with Hešen's case last year, Nayancheng was a grand councillor. I saw that he was intelligent in answering questions and discussing issues, seeming to be greatly promising. In addition, he was the grandson of the late Duke and Grand Secretary Agūi. I did expect him to carry on his family's fame, and to undertake important responsibility. Thus I repeatedly granted favour to him, promoting him to the positions of minister and banner commanderin-chief, and letting him take charge of the Ministry of Revenue, the Three Treasuries, and the revenue collection at the Chongwen gate, as well as other duties. It was true that he had been given more titles than others, for I intended to cultivate him to become someone useful. It was not because I was just partial to Nayancheng personally. ${ }^{21}$

Yet, there was one obstacle in the way of Jiaqing's catapulting Nayancheng to the status that Hešen had possessed: Nayancheng's empty slate of merits. For Nayancheng who had not been either a territorial administrator or a military commander, some battleground experience would make up for the gap in his credentials, qualifying him to be the chief grand councillor, and would quell the criticism among officials who were vigilant against the rise of a new crony.

After both Necin and Fuheng had been sent to lead military campaigns, successful or not, it became a tradition for Qianlong to baptise his chief grand

supervisor of the Chongwen Gate customs (Ibidem, vol. 4, 40). Then he was ordered to act as the minister of war while the minister was on sick leave (Ibidem, vol. 4, 46; QSLJQ, 39/6a). On 14 March, Nayancheng, along with Zhu Gui, was appointed as the deputy director of the Historiography Institute (Ibidem, vol. 4, 59). On 29 June, Nayancheng was named to be in charge of the Palace Maintenance Office (Ibidem, vol. 4, 182). On 25 August, Nayancheng was appointed as director of the Imperial Household Department, although his position as the president of the Hanlin Academy was taken away (Ibidem, vol. 4, 259).

20 In addition to his position as the vice-commander-in-chief of the Mongol Yellow Banner, Nayancheng was appointed as the commander-in-chief of the Chinese Bordered White Banner in 1799. QSLJQ, 39/4a.

21 Edict on JQ 05/05/25 (Jiaqing reign and year/month/date in the Chinese lunar calendar), JQQJZ, vol. 5,368 . 
councillor on the battlefield. In 1781, when the Salar Muslims revolted in Gansu, Qianlong sent Hešen, a courtier without any military orientation, as a 'Special Imperial Commissioner.' But he failed to score a victory. Not until Agūi, the campaign's commander-in-chief, arrived were the rebels routed and the uprising put down. Although Qianlong was not pleased with Hešen's performance at the front and called him back before long, the speedy suppression of the revolt gave Hešen a passing grade for his internship. He was soon appointed to act as minister of war. ${ }^{22}$ Apparently, the Qianlong emperor attached great importance to his primary aide's military capability and held it as a crucial qualification for leading the Grand Council. An avid student of the history of the Qing dynasty, Jiaqing had evidently read the 'Veritable Records' of all his predecessors. In many ways, Jiaqing consciously mimicked his father. If he invoked Necin's death when he ordered Hešen to commit suicide, he hoped that Nayancheng would become another Fuheng and bring an end to the ongoing campaign against the White Lotus rebels.

After the purge of Hešen, Jiaqing was, at first, hesitant to drastically revamp the leadership of the suppression campaign against the White Lotus rebels in central China. Nevertheless, when no breakthrough had been made for months, Jiaqing reshuffled the war leadership. He dismissed Lebao, the commander-in-chief, and appointed Eldemboo, a veteran Manchu general, as the new commander-in-chief bearing the title Grand Minister Commander. Meanwhile, he sent several high-ranking officials known for their integrity and outspokenness to the Sichuan theatre to take charge of war finances. For the Shaanxi theatre, Jiaqing was increasingly upset with Mingliang, a senior Manchu general who had been Agūi's deputy in many wars in the later part of the Qianlong period. Chiefly due to his infighting with Yongbao, the governor of Shaanxi, Mingliang deliberately delayed his operations, failing to finish off a rebel band led by Zhang Hanchao, a sectarian leader of Xiangyang. As a result, a few thousand of Zhang's men shuttled back and forth on the north bank of the Han River for more than a year. ${ }^{23}$ Jiaqing thought it

22 The Salar Muslim uprising originated from an internal strife between the different Muslim schools. The Qing local authorities sided with the Old School and arrested and executed Ma Mingxin, the leader of the New School, which prompted the New School Muslims to attack Lanzhou, where Ma had been held. On Hešen's participation in the war, see his biography in Qingshi Liezhuan, vol. 5, 216-218.

23 Yongbao was the first commander-in-chief of the suppression campaign. He was dismissed and sent back to Beijing for trial at the end of 1796 . However, he was reinstated in 1798 when his brother, Lebao, became the commander-in-chief. Because Mingliang was a colleague of their father, Wenfu, during the second Jinchuan war (1770-1776), Mingliang was loath to work under his former colleague's sons. 


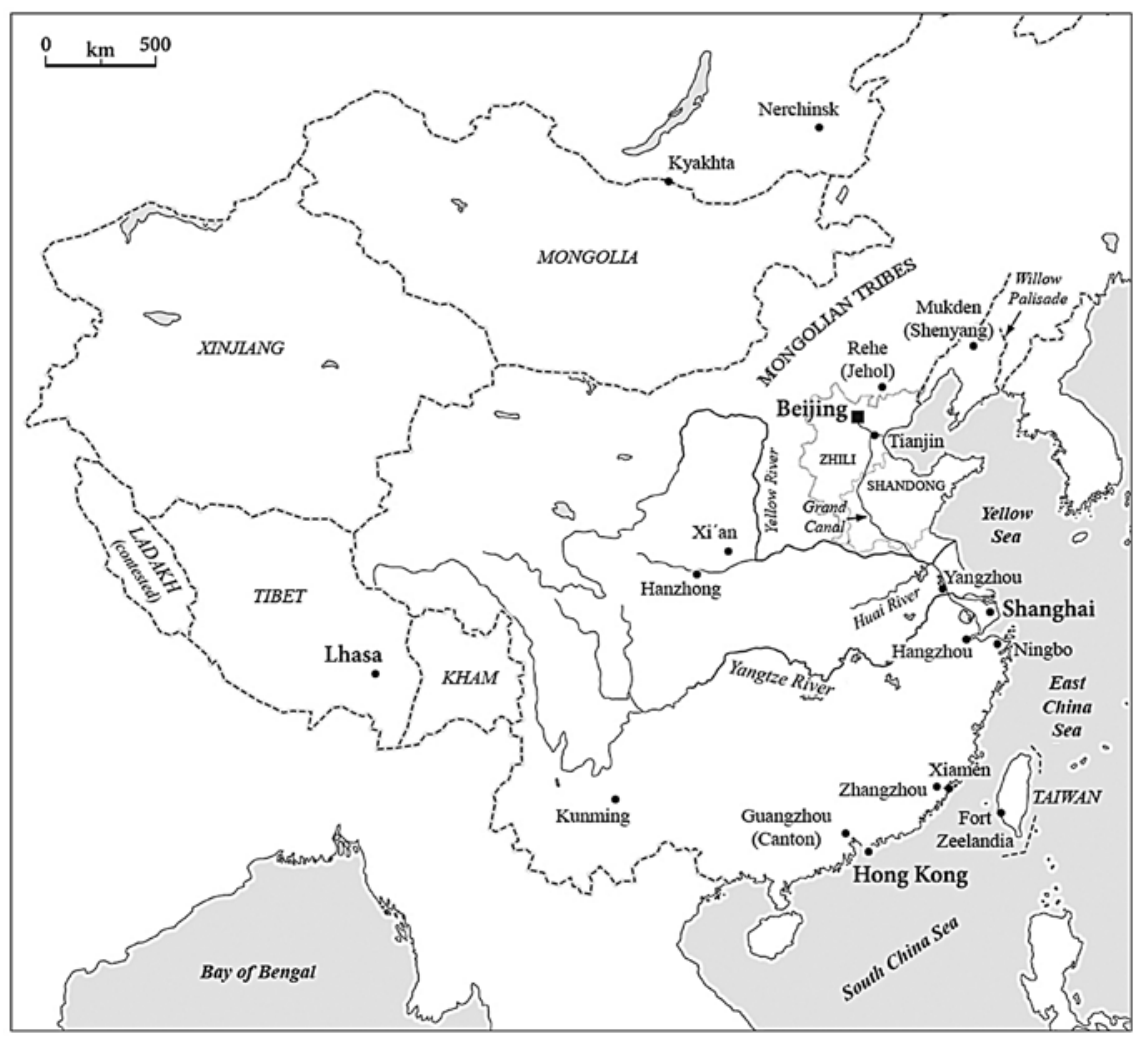

FIGURE 1 Map of Qing China, adapted and translated from Barend J. Ter Haar, Het hemels mandaat: de geschiedenis van het Chinese keizerrijk (Amsterdam, 2009), 381.

therefore necessary to send a commissioner from the capital to Shaanxi to spur Mingliang to work harder.

Perhaps with all those considerations in mind, on 22 September 1799, Jiaqing appointed Nayancheng as a 'Special Imperial Commissioner' to Shaanxi. His primary duty was to supervise Mingliang in eliminating Zhang Hanchao's band, but he was instructed to join the operations himself. ${ }^{24}$ Concerned about Nayancheng's lack of military background-Jiaqing once called him a 'bookish scholar,-—Jiaqing told Mingliang that he could redeem his 'crime' if he successfully assisted Nayancheng and warned him not to take Nayancheng lightly or be jealous of him. ${ }^{25}$ Before Nayancheng's departure, Jiaqing granted his widowed mother an honourable title to commend her parenting Nayancheng

24 XFFL, 117/34a-41a, 119/20a-b, 120/20a-b; QSLJQ, 50/31a.

25 XFFL, 120/9a-11a, 140/34b, 154/46b-47a. 


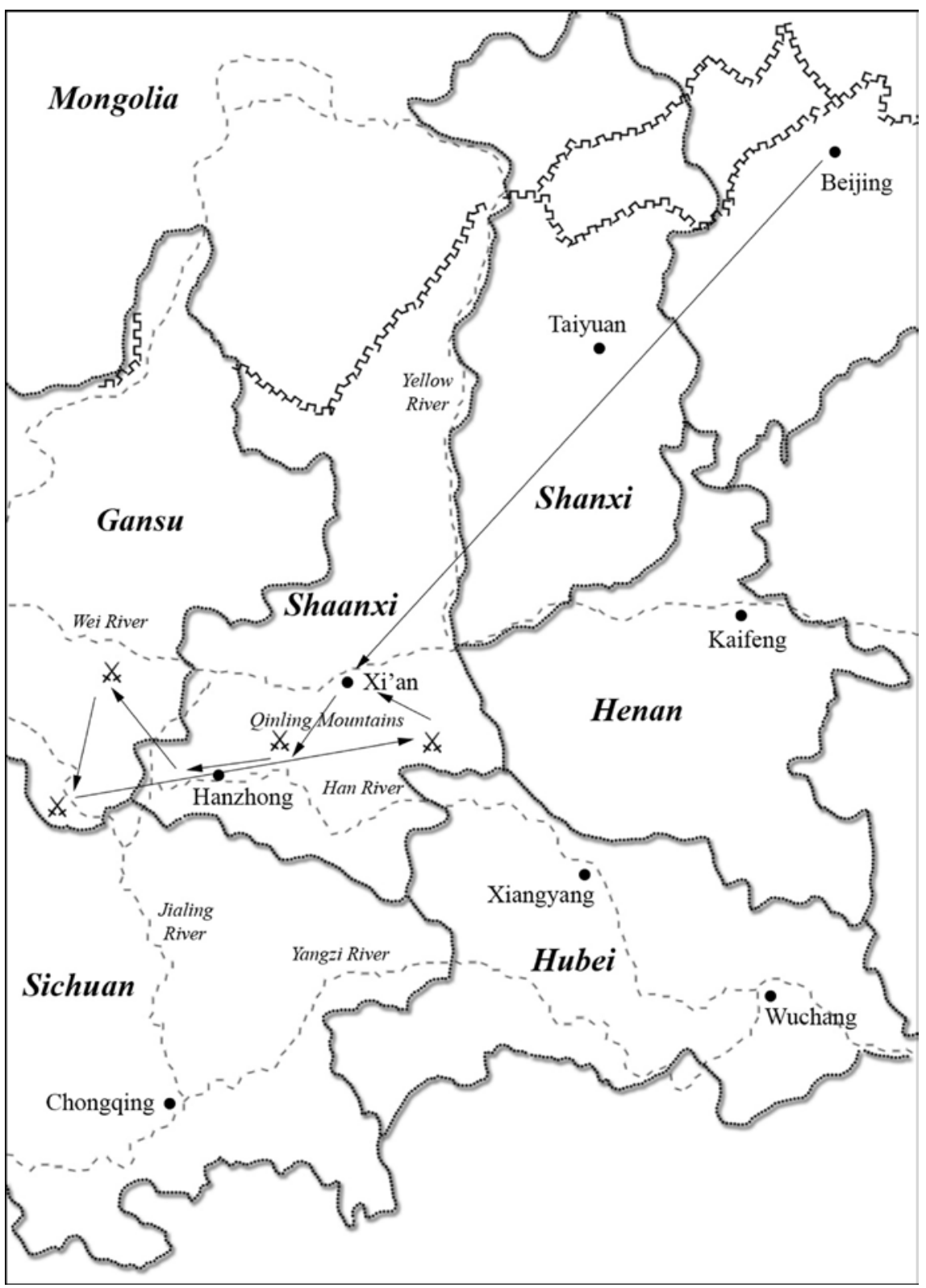

FIGURE 2 Map of Nayancheng's travels and major battles. 
alone after the death of her husband Asida. ${ }^{26}$ Jiaqing also placed Adisi, Agūi's youngest son and Nayancheng's uncle, in the position of the Chengdu General, so that he would join the suppression campaign as well. ${ }^{27}$ As Hengrui, the Xi'an General and Nayancheng's father-in-law, had been at the front since the start of the rebellion in 1796, there were now three of Agūi's relatives in the leadership of the campaign.

\section{An Unpromising Debut}

Nayancheng set out for Shaanxi province early in October 1799. Along with him was Taibu, a Mongol bannerman and the new governor of Shaanxi to succeed Yongbao, who had been cashiered. On their way to the front, the two tried to discover the reasons for the lacklustre state of the operations in the Shaanxi theatre. Having interviewed local officials, soldiers, military family members, and even servants and valets, they were convinced that the field commanders in Shaanxi had not committed themselves to the fight; indeed some might not have engaged the rebels for months. An upstart, Nayancheng was eager to exercise his authority and requested authority to impose capital punishment, before royal endorsement, on any generals on site, if he could confirm their serious misconduct. He argued that he was not lightheaded and reckless in requesting this authority, but he was determined to root out the entrenched warfront malpractice. However, Jiaqing bluntly rejected the request. Pointing out that one should not take high-ranking officials' lives lightly, he said that even the Grand Minister Commanders had never had this prerogative, let alone a Special Imperial Commissioner, who was lower in authority. ${ }^{28}$ Despite his unwavering trust in Nayancheng, the emperor was concerned about the new commissioner's pretentions.

When Nayancheng arrived in Shaanxi, Mingliang had just won a battle against Zhang Hanchao, who committed suicide in the wake of his defeat. However, Jiaqing dismissed Mingliang and put him on trial anyway, because Yongbao had accused Mingliang of exaggerating his victories, and, much worse,

\footnotetext{
26 JQCSYD, vol. 4, pp. 158-159; QSLJQ, 44/22a-b.

27 XFFL, 119/20a-b.

28 Meanwhile, Nayancheng requested more elite bannermen from Manchuria, which was also rejected by Jiaqing, because he had just sent 3,00o bannermen from Shengjing and Jilin, and 1,00o Salar soldiers from Gansu, to Shaanxi. Nayancheng and Taibu's memorial, JQ 04/o9/14, in Qing Zhongqi Wusheng Bailianjiao Qiyi Ziliao (Nanjing, 1981-1982), vol. 1, 428-430; XFFL, 121/1a-9a; QSLJQ, 52/4a-5a.
} 
fabricating in his reports battles that had not been fought. With Mingliang gone, Jiaqing let Hengrui team up with Nayancheng and coach his son-inlaw in his warfront apprenticeship. ${ }^{29}$ Meanwhile, Nayancheng was poised to battle warfront corruption. Since rewarding troops had been one of the main loopholes for the commanders to misappropriate war funds, Nayancheng and Taibu proposed to take money out their own income for rewarding the troops and militiamen. Again showing his favour to Nayancheng, Jiaqing declined his request on the basis that Nayancheng had to support his widowed mother and family. Instead, he granted Nayancheng 6,00o taels of silver for the purpose. But Jiaqing granted Taibu's request. ${ }^{30}$ In fact, Nayancheng had numerous salaries and subsidies due to his many concurrent positions; the sacrifice of one or two of them would not have greatly affected his family's livelihood. To Taibu, however, it was a substantial financial loss.

Having reached the frontline in the depths of the Qinling Mountains in southern Shaanxi, Nayancheng and Taibu took over Mingliang's army. Joined by 4,00o bannermen newly deployed from Manchuria, they had a sizeable army consisting of more than 10,000 men. Nayancheng's charge was to first clear out all Zhang's remnants, a few hundred or perhaps one thousand odd rebels, and then fight other insurgent bands in southern Shaanxi. Even though it was already December, the emperor pushed for completing the campaign before Chinese New Year at the end of January, $1800 .{ }^{31}$ Despite his superiority in military force, Nayancheng faced treacherous conditions in the mountains. While he tried to hide his concerns in front of his subordinates, he was candid with the emperor. In his first reports from the frontline- he did not send in his reports until weeks after his arrival, likely trying to figure out a strategyNayancheng confessed to the emperor many obstacles in the way. The snow and ice and lack of paths made it difficult for the Qing troops and their cumbersome logistical corps to move fast. The insurgents, however, were more conversant with the conditions in the mountains since they had trekked through them several times. In addition, they were burden free because they supplied

29 Unwilling to be commanded by his former colleague's grandson-Mingliang had been deputy to Agūi in several wars during the Qianlong reign—Mingliang had stepped up his operations in order to wipe out Zhang's band before Nayancheng's arrival. XFFL, 119/19a, 120/5b-9a, 122/1a-4a, 122/6a-13b, 122/19b-20b, 125/1a-7a, 125/17a-21b, 125/23a-b.

Nayancheng requested to take in advance five years of his stipend as minister of works ( 360 taels per year) and his 'silver to nourish virtue' allowance as the Manchu commanderin-chief (6oo taels per year); the total amount was 4,800 taels. Taibu requested to take two years of 'silver to nourish virtue' allowance as the governor of Shaanxi. XFFL, 131/10a12a, 133/14b-15b, 133/16a-b, 133/19a-20a.

31 XFFL, 131/3a-5a. 
themselves by looting the refugees in the mountains. Nayancheng complained that it was not possible to surround the enemy and make use of pincer attacks and that the denseness of trees and bushes compromised the effect of firearms and bows. Apparently at a loss, Nayancheng requested more bannermen as his force had become smaller because he left troops to guard the passes. ${ }^{32}$

Nayancheng's pessimism upset Jiaqing who was anxious for a triumph. Since sending Nayancheng to the front was virtually his last resort, Jiaqing was despondent: 'If even Nayancheng could not do the work on time, who else should I send? Do those petty bandits deserve an expedition led by myself?'33 Blaming everything Nayancheng had done or suggested, the emperor explicitly verbalised his growing disappointment. He ended his edict to him with the rare expression, 'tearfully instructing. ${ }^{34}$ It was not unusual in Qing history for the monarch to be exacting on his field commanders. Both the Yongzheng and Qianlong emperors had often been so, when both tried to direct a war from their palace, far from the frontline. Back in the late 1740s, when the Qianlong emperor sent Fuheng to the first Jinchuan war, Qianlong was similarly demanding of the junior grand councillor, urging him to end the war immediately by sending him an edict almost every day. With the help of Yue Zhongqi, Fuheng had the luck to settle the war soon after he arrived at the front. Nayancheng, on the contrary, did not have such a person to help him. Mingliang was dismissed. Taibu was a civil official, and also new to the area. Hengrui was not a first-rate general. In his late fifties, Hengrui had become much slower than he used to be by the time Nayancheng came to the war.

But Nayancheng had his youthful courage and burning desire for success. After having encountered the insurgents eight times in ten days since his arrival at the frontline, he had not gained any decisive victory, save killing dozens to scores of rebels each time, as the insurgents immediately ran into the forest once they met the Qing forces. Convinced that the only way to deal with his enemies' guerrilla warfare was to adopt guerrilla warfare techniques himself, Nayancheng de-equipped his troops and sent them into the forest in dispatches. Leading one of the detachments, Nayancheng himself entered the forest as well. At times he had to dismount, and walk on foot where horses could not pass. ${ }^{35}$ However, the Jiaqing emperor again disapproved, thinking that it was simply reckless for Nayancheng, or any major commander, to go into the primeval forest to pursue the rebels and unwise to position the elite

\footnotetext{
$32 \quad \mathrm{XFFL}, 131 / 6 a-10 a, 133 / 12 b-14 b$.

33 XFFL, 131/20a-b.

34 XFFL, 131/17b-20b, 132/3ob-32a.

35 XFFL, 133/9b-12b, 135/18a-20b, 136/19b-23a.
} 
Manchu bannermen in a place where their advantages were negated. Jiaqing ordered him to choose able troops to go into the forest and drive the rebels out so that the main Qing forces could finish them up in the open. He also suggested that they could even burn the forest to this end. ${ }^{36}$

Despite Jiaqing's chagrin and repeated order that Nayancheng pull out of the forest, Nayancheng strenuously resisted the command. ${ }^{37}$ But Jiaqing was adamant. Furthermore, he was annoyed that Nayancheng did not keep all the theatres in his purview. He could not help but utter that Nayancheng was 'unreliable.' Given that Nayancheng was fighting a small band of rebels with his massive force, Jiaqing ordered Nayancheng to transfer 1,00o Manchurian bannermen to Eldemboo, the commander-in-chief of the campaign who had been in the Sichuan theatre. Nayancheng refused, insisting that those bannermen were indispensable to him and that his own troops were not sufficient. ${ }^{38}$

III The Mission Fails

At the beginning of 1800 thousands of insurgents from Sichuan penetrated the south-western corner of Shaanxi, from where they invaded Gansu, a province that had been largely free of unrest. Jiaqing immediately ordered Nayancheng to rush to Gansu and tackle the rebels there. At this time, Zhang's remnants numbering in the hundreds had moved out of the Qinling Mountains and run eastward rapidly to Shaanxi's borders with both Henan and Hubei. Although Nayancheng claimed that he had driven out the rebels, Jiaqing did not believe this claim but thought that the rebels had fled because they had run out of supplies. Beyond the Qinling Mountains, Nayancheng again failed to give his enemies a death blow. He instead pressed them in the direction of Henan and Hubei. Alarmed and enraged, Jiaqing reprimanded Nayancheng severely, ordering him to stop those insurgents from going to either Henan or Hubei. Not until Nayancheng managed to force the rebels to turn westward, away from Shaanxi's south-eastern borders, did Jiaqing relax, and again order him to hurry to the Gansu front. ${ }^{39}$ Nayancheng obeyed this time. Leaving Taibu and several lesser generals in Shaanxi to finish off the last of Zhang's men,

\footnotetext{
$36 \quad$ XFFL, 133/16b-19a, 135/2ob-22b.

37 XFFL, 138/20a-24a, 138/25a-b.

38 XFFL, 138/27a-31b, 142/12a-14b.

39 XFFL, 138/7b-12a, 139/9b-10a, 139/13b-14a, 140/8b, 140/10b-12b, 140/16a-18a, 142/18a-20a.
} 
he and Hengrui set out for Gansu at the beginning of February. ${ }^{40}$ Meanwhile, Eldemboo also headed to Gansu from Sichuan.

Learning of Nayancheng's move to Gansu, Jiaqing must have felt relieved, as he had been under mounting pressure in the capital, where Nayancheng's meteoric rise had triggered heated speculations and suspicion. The emperor's censures of Nayancheng through official communication conduits only encouraged the further questioning and scrutiny of the probable successor to the fallen Hešen. Jiaqing had been hearing many rumours against Nayancheng. As Hešen's subordinates had been attacked in order to discredit Hešen before his fall, some in the court accused Nayancheng's retainers of having pressed the local officials for bribes during Nayancheng's trip to Shaanxi, although it had been a widespread practice for the local officials to send gifts, including money, to travelling high-ranking officials. When Jiaqing sent an edict criticising Nayancheng for failing to discipline his retainers, Nayancheng vehemently defended himself, arguing that he had been extra careful, for he knew the importance of image-building. ${ }^{41}$ Alone, one night late in the February, Jiaqing wrote a few lines on Nayancheng's self-defence memorial, confessing to the commissioner his high expectations and the pressure he was under:

What you have done after you were sent to Shaanxi has trapped you in a dead-end; you have not achieved any success after you went into the forest, despite your hard work, trekking in the mountains, and wetting your clothes by wading through rivers. I have been worried about you days and nights. My heart has followed you without a moment of parting you! There have been so many talks [about you], some saying that you are supercilious, the others saying that you are incapable. But I always brush them aside with a smile, because I am waiting for your news of victories. [When they come] all the rumours can be silenced. If you fail to repay such a great favour from me, you do not deserve to be the grandson of the empire's prime minister.

$40 \quad$ Nayancheng and Taibu's memorial, Gongzhongdang, No. 19771 (housed in the National Palace Museum, Taipei; hereafter cited as GZD ); JQ 05/01/06, Nayancheng and Hengrui's memorial, JQ 05/01/12, GZD, No. 4738. XFFL, 141/28b-29b, 144/12b-13b, 142/20b-26a, 144/12b-13b.

Nayancheng argued that he had notified the local officials along his way not to send him gifts and that he instructed them not to come out to greet him once he entered the mountains to fight the rebels. He also sent back 20 sedan-chair carriers who had served him after he had arrived at the front. After one of his retainers had had a confrontation with soldiers and local residents while purchasing liquor, he submitted him to the legal commissioner of the province for punishment. QSLJQ, 58/28b-29a. 
At the end, Jiaqing added: 'I wrote the above under the lamp in secret, and nobody is beside me. You should place this memorial [with Jiaqing's handwritten comments] in a safe place, and return it to me in person when you come back to Beijing. ${ }^{42}$ The confidential communication between the emperor and Nayancheng was reminiscent of the story that the Yongzheng emperor had maintained intimate and frequent correspondence with Ortai, one of his most trusted officials as well as his consultant, in the 1720 s when Ortai was the governor-general in the far southwest. In that case, the emperor had discussed many state issues with Ortai through the long-distance correspondence along with the exchange of personal feelings. ${ }^{43}$ But Jiaqing was uncertain and even nervous about his relationship with the would-be first aide. Although Jiaqing made clear his intention of placing Nayancheng in Hešen's position in his message, he could not help but show that it would be difficult should Nayancheng fail to prove himself in this mission. The emperor's growing vexation would, in turn, put more pressure on the commissioner to achieve significant victories.

After he arrived in the north-western border region of Gansu via Shaanxi's Baoji, Nayancheng finally produced two victories late in February. In fact, Nayancheng was lucky in both battles. In the first battle in Qin'an, the Qing forces easily crushed their enemies because the latter had been burdened by carrying with them thousands of coerced civilians as well as large numbers of draft animals and livestock. Nayancheng claimed that his troops killed and captured more than 3,00o, with only a couple of his troops slightly injured. In the second battle near the seat of Fuqiang county, Delengtai, a Mongol bannerman and another leading general in the suppression campaign, happened to arrive and give a hand to Nayancheng. Whatever Nayancheng's personal contribution to the victories may have been, the pleased Jiaqing praised Nayancheng loudly and rewarded his troops with a one-month stipend, which was the first time that the emperor had granted any reward to Nayancheng's forces since his arrival at the frontline in late $1799 .{ }^{44}$

42 QSLJQ, $58 / 29 \mathrm{~b}-30 \mathrm{a}$. Those few sentences were in addition to a more formal rescript, which might have been drafted by the grand councillors. This private note was included in the Jiaqing emperor's 'Veritable Records', most likely by mistake because the confidential correspondence should not have been included.

43 On the intimate relationship between the Yongzheng emperor and Ortai, see Guy, Qing Governors and Their Provinces, 334-348; Lai Hui-min, 'Lun Qianlongchao Chuqi zhi Mandang yu Handang', in Qingdai de Huangquan yu Shijia, 157-161, and Yingcong Dai, The Sichuan Frontier and Tibet: Imperial Strategy in the Early Qing (Seattle, 2009), the fourth chapter, 'Realignment in the Yongzheng Period, 1723-1735', 91-116. 
But Eldemboo's arrival in Gansu shortly after complicated Nayancheng's agenda. Although Eldemboo was the commander-in-chief of the entire campaign, bearing the paramount military ad hoc title, the Grand Minister Commander, he was from a humble Manchu family and illiterate in Chinese, a contrast with Nayancheng's noble pedigree and jinshi degree. In fact, Jiaqing had been concerned about this discrepancy. Thus he had repeatedly instructed Nayancheng to cooperate with Eldemboo and not be arrogant or unwilling to obey him. ${ }^{45}$ Yet Nayancheng could not hide his haughtiness. He demanded from the throne another ad hoc title, Canzan Dachen, or 'Grand Minister Consultant', which would make him a deputy to the Grand Minister Commander. Jiaqing agreed, but without enthusiasm. After Nayancheng and Eldemboo joined forces on 4 March, Jiaqing let Nayancheng lead all the troops in Gansu, including Eldemboo's because the latter was ill. However, Jiaqing did not back Nayancheng's bid for the top place in the campaign leadership. ${ }^{46}$ After their meeting in Gansu, the two cooperated in a couple of battles, but Eldemboo did not hand the reins of his troops over to Nayancheng. Although Nayancheng deliberately sent a memorial to reassure the emperor of his good relationship with Eldemboo, the two separated soon, going different directions in Gansu. ${ }^{47}$

looted and burned by the rebels, and let villagers kill them in whatever ways they chose. Nayancheng's memorial, JQ 05/01/27, GZD, No. 4859; Nayancheng, Delengtai and Hengrui, JQ 05/02/05, GZD, No. 4972; XFFL, 147/35a-40a; 151/1a-7b.

45 When Nayancheng stated in a memorial that he and Eldemboo had been good friends since he was small, and it was unlikely that he would get into conflict with him, Jiaqing replied: 'Friendship from the time of being poor and humble might not last when people become wealthy and noble.' Nayancheng's memorial, JQ 05/01/06, GZD, No. 19773; XFFL, 138/7b-12a, 139/13b-14a, 140/8b, 142/28b.

46 Ignoring Nayancheng's overtures, Jiaqing let Eldemboo keep his seal of Grand Minister Commander but did not give Nayancheng a new seal of Grand Minister Consultant. Instead, Jiaqing wanted him to continue using his seal of Special Imperial Commissioner. Eldemboo and Nayancheng's memorial, JQ 05/02/11, GZD, No. 5023; XFFL, 147/38b-39a, 147/48b-49b, 152/1a-2b, 152/7a-9a.

In his memorial, Nayancheng said: 'Eldemboo has long been experienced in military and wars, and is fair and loyal. He and I have been good friends. I have consulted him on all the military matters and listened to his careful directions. This is my first time to be in a war. I have benefited greatly from learning from him.' JQ 05/03/03, GZD, No. 5267 . It is unusual for Nayancheng to send a memorial just for claiming his good terms with Eldemboo, which in fact indicates some discord between them. Only one week later, the two separated. For their brief cooperation and abrupt separation, see Eldemboo and Nayancheng's memorial, JQ 05/03/03, GZD, No. 5266; Eldemboo and Nayancheng's memorial, JQ 05/03/o9, GZD, No. 5315; XFFL, 157/1a-6a. 
The departure of the crack Qing forces for Gansu left the Shaanxi theatre vulnerable; more rebel bands arrived from Sichuan, precipitating Shaanxi into crisis. Jiaqing sent first Hengrui and then Eldemboo back to Shaanxi, and charged Nayancheng with finishing off the remaining rebels in Gansu. ${ }^{48}$ With Hengrui leaving for Shaanxi, Nayancheng paired with Qingcheng, a Chinese bannerman and a seasoned general. ${ }^{49}$ Early in April, they caught the disarrayed rebels in Wen county bordering Sichuan's Longan prefecture and routed them while the rebels were attacking a make-shift castle that sheltered over 10,000 local residents. However, the core of the rebel band in the hundreds escaped into the forests on the borders between Gansu and Sichuan. As the focus of the campaign had shifted to Shaanxi, Nayancheng was eager for opportunities to distinguish himself there. So he requested to go back to Shaanxi and to let the troops in Sichuan mop the remaining rebels up. Jiaqing agreed. Yet he was 'very unhappy' about Nayancheng's leaving the band alive, so much so that he did not give any rewards for their victory. ${ }^{50}$

Indeed, Nayancheng's premature departure from Gansu upended his two-month campaign there. The remnants of the rebel force, including several key leaders of the White Lotus Rebellion, soon crossed the border to Sichuan's Longan and Songpan prefectures, and swelled their ranks with new recruits. ${ }^{51}$ As Chengdu, the provincial capital, was threatened by the rebels, the deeply concerned Jiaqing harshly criticised Nayancheng and Eldemboo in one after another edict. To Nayancheng, he was relentless: he ordered the reduction or elimination of Nayancheng's records of merit earned in the victories in Gansu. ${ }^{52}$ The resurrection of this rebel band in northern Sichuan was the last straw that crushed Jiaqing's lingering confidence in him. However, another exigency

48 XFFL, 154/46a-48a, 155/1a-7b, 156/40a-41b, 158/1a-2b, 158/14a-20b, 16o/12b-17a, 160/20a23b, 162/8b-1ob. Eldemboo instantly headed back to Shaanxi upon receiving the edict in early April. XF FL, 161/11a-14b.

49 Qingcheng's last name was Sun, and he was the great grandson of Sun Sike, a renowned Chinese general during the Kangxi period. Being Mingliang's deputy in the lacklustre operations against Zhang Hanchao before Nayancheng's coming, Qingcheng was dismissed and exiled to Xinjiang. When he passed Gansu, the rebels came, so that he was reinstated and ordered to join the operations in Gansu.

50 Again, many of the more than 1,000 who had reportedly been killed or captured were women and children. Jiaqing did not punish Nayancheng for his not chasing the rebels to Sichuan, citing the hardship he had endured, and the fact that he had at least killed many rebels and rescued the civilians in the castle. XFFL, 163/1a-9a, 163/29b-30a, 167/13b-15a.

$5^{1}$ Songpan used to be part of Tibet's Kham area. There were also Tibetans and other nonChinese ethnic peoples in Longan. XFFL, 165/1a-7a, 166/40a-41a.

$5^{2} \quad$ XFFL, 165/13b-16b, 165/30a-33b, 166/5b-12b, 167/11a-b, 167/13b-15a. 
prolonged Nayancheng's mission for one more month. After Nayancheng returned to Shaanxi at the beginning of May, the rebels in south-eastern Shaanxi were poised to cross the borders to Henan, which temporarily diverted the emperor's anger with Nayancheng. Both Nayancheng and Eldemboo were hurried to the border. Once again, Nayancheng failed to score any decisive victory but was keen in competing with Eldemboo. ${ }^{53}$ Finally, it was Eldemboo who forced all the rebels away from Shaanxi's borders with Henan late in May. The crisis was solved. ${ }^{54}$

\section{The End of a Tradition}

As soon as he knew that Henan was secured, Jiaqing called off Nayancheng's mission on 7 June 1800 , ordering him to hand over all his troops to Eldemboo and return to the capital. As for the reason, Jiaqing only briefly stated that Nayancheng 'has not expeditiously completed the operations. ${ }^{55}$ However, when the news arrived on the following day that Shi Jin, a meritorious senior Chinese general, along with several other officers, had been killed in a battle in Sichuan's Longan by the rebels who had escaped from Gansu, Jiaqing lost his composure. Attributing Shi Jin's death to Nayancheng's early withdrawal, he harshly repudiated Nayancheng, reiterating all the mistakes he had committed in his mission. More particularly, he blamed Nayancheng for trying to compete with Eldemboo by returning from Gansu prematurely. Therefore he deprived Nayancheng of most of his titles, including his positions on the Grand Council,

53 In mid-May, Nayancheng had fought an all-day battle with a group of 20,000 rebels, killing hundreds, but Jiaqing was not pleased, as Nayancheng once again allowed the band to escape without eliminating it. Jiaqing did not grant him and his troops any reward. XFFL, 170/18a-22b, 170/25a-26b. Because the emperor had tried to give 1,000 or 2,000 of Nayancheng's troops to Eldemboo, who had had a smaller force, Nayancheng pushed Eldemboo to join him to request reinforcements. Having not granted any when the two had asked for reinforcements when they were in Shaanxi, this time Jiaqing reluctantly agreed to send 6,00o reinforcements to Shaanxi. XFFL, 157/6a-8b, 157/18a-2ob, 159/13a14b, 161/14b-19a, 167/24a-33a. Jiaqing was irate at both Eldemboo and Nayancheng, criticizing both severely, and stripping them of their feather trappings, the emblem of their status. XFFL, 168/16b-24b, 168/30b-32b.

54 At this time Jiaqing gave back the feather trappings to Eldemboo and Nayancheng. XFFL, 171/1a-6a, 172/1a-9b.

55 It was included in a long edict criticising both Nayancheng and Eldemboo for their having no overall and workable plan when he received a joint memorial from them. XFFL, 173/22b-33b. 
at the Imperial Study, and in the Imperial Household Department, and the privilege of riding horses inside the Forbidden City. Yet, Jiaqing maintained Nayancheng in three positions: minister of war, vice-commander-in-chief of the Chinese Bordered White Banner, and the lectureship at the Classics Colloquium. He explained that he would have felt sorry if none of Agūi's offspring had been in the high rank, given that he had just cashiered Adisi, Nayancheng's uncle, and exiled him to Xinjiang, due to his incompetent performance in the Sichuan theatre. ${ }^{56}$

Completely demoralised, Nayancheng did not request to stay at the front, as the emperor had expected. He immediately packed and went home. In the middle of July, ten months after he was sent to the war, Nayancheng returned to Beijing. For several days Jiaqing met privately with him, in a faint attempt to salvage him from total downfall if Nayancheng put on a convincing self-defence. However, overwhelmed by his own calamity, Nayancheng did not offer any useful analysis of the warfront situation and his strategy to wrap up the lingering campaign. Instead, he was negative, uninterested, and, at times, disoriented. He told the emperor that the rebels were like locusts that were too numerous. He also said that the rebellion was due to a predestined doom; if fate had not yet run its course, even the most brilliant generals could not do much. When Jiaqing told him of a critical victory Eldemboo had achieved immediately after he had left, he shrugged it off in a gesture of disbelief. Displeased by these responses, Jiaqing made up his mind to sacrifice Nayancheng. ${ }^{57}$ On 17 July 1800 , Jiaqing stripped Nayancheng of his last three positions. Again, the fact that he was Agūi's grandson saved him from being exiled to Xinjiang. Reduced to being merely a member of the Hanlin Academy who would partake in editing the emperor's 'Veritable Records', Nayancheng returned to where he started his career a decade earlier. ${ }^{58}$

A number of factors contributed to Nayancheng's failure at the warfront. He was inexperienced in war, let alone operating in extremely inhospitable terrain. He was opinionated and intractable, which had alienated him from his colleagues and, more importantly, the emperor. Moreover, Nayancheng's rivalry with Eldemboo, driven by his eagerness for achievements and, perhaps, his contempt for the latter, only made his isolation worse. In the edict to ostracise Nayancheng, Jiaqing said: 'Outwardly, Nayancheng seems to be bright, but

$56 \quad$ Jiaqing also allowed Nayancheng to keep the feather trappings that had been just returned to him. XFFL, 174/6a-13a, 174/19b-23b, 174/32a-34b. For Adisi's dismissal and punishment, see JQQJZ, vol. 5, 183-184, and 289-290.

57 JQQJZ, vol. 5, 368-373; QSLJQ, 68/11b-24b.

$5^{8}$ JQQJZ, vol. 5, 374-375. 
he has no strength of mind. Not being sharp in his views, he is indecisive when it comes to critical matters. He is conceited, and unable to listen to others. 59 Although it might not be a true reflection of his inner feelings for Nayancheng, this comment catches well Jiaqing's frustration. ${ }^{60}$

His haughty personality aside, Nayancheng faced a difficult situation at the front. Having capitalised on the campaign for personal gains for years, many commanders and local officials in the war zones were resistant to reform and hostile to the reform-minded leaders sent by Jiaqing. By the beginning of 1800, the warfront reform had hit a dead-end. Conservative and diffident in nature, the Jiaqing emperor had been neither willing, nor able, to risk upsetting the status quo. In fact, his calling off Nayancheng's mission was part of a full-scale retreat from his bold but ephemeral reform. Besides Nayancheng, Jiaqing also dismissed or transferred from the front several other reformers. By the time of Nayancheng's dismissal, all new leaders sent to the war in the wake of Hešen's purge had left (one of them was given the death penalty due to military debacles in the Sichuan theatre). ${ }^{61}$ During the remaining years of the suppression campaign, which did not end until the middle of 1805 , Jiaqing sent no other commissioner from the court to the warfront; he basically bowed to the delaying tactics of the old guard, as well as their squandering and siphoning off of war funds.

Nayancheng's downfall can be charged to the changed political climate in the post-Hešen era. Riding the momentum of denouncing Hešen's domination of the court, which often bordered on implicating Qianlong's connivance at it, the officials and courtiers had openly questioned and opposed Jiaqing's intention of making Nayancheng another royal crony. In order to quell criticism, Jiaqing had to sacrifice Nayancheng. Had the opposition not been so strong, Jiaqing could have anointed Nayancheng into the position left by Hešen no matter what he had or had not accomplished at the front, given that Hešen's pathetic performance in the Muslim campaign had not impeded his further ascent. Early in 1802, Jiaqing was still on the defensive, claiming in an edict

59 JQQJZ, vol. 5, 374.

6o Jiaqing might have still thought highly of Nayancheng. After Nayancheng was reinstated, Jiaqing wrote to him in 1804, saying of him: 'You are truly one of the officials who are the pillars of the country, having both ability and virtue.' But he also warned him not to be too arrogant but to listen to others' opinions. Zhao Erxun, Qingshigao, 11460.

61 The official who received the death penalty was Kuilun, the governor-general of Sichuan. Lebao, the dismissed commander-in-chief and the mastermind of delaying tactics, was reinstated to succeed Kuilun. I detail the warfront reform and its failure in the fourth and fifth chapters of my book manuscript, 'The White Lotus War.' 
that both the Qianlong emperor and he had never given too much power to any grand councillor, but had tightly held the power in their own hands. ${ }^{62}$ As Beatrice S. Bartlett has pointed out, this statement discloses the pressure from the bureaucracy on Jiaqing to reduce the dominance of grand councillors in the central government. ${ }^{63}$ It was also aimed at, in this author's opinion, mending his fences and obliterating his failed attempt at catapulting Nayancheng to the summit, which had aroused potent dissension from officials.

In the spring of 1801, Nayancheng was humiliated one more time when Jiaqing sent to him a memorial by Eldemboo reporting his elimination of the rebel band that Nayancheng had allowed to escape to Sichuan. Nayancheng kowtowed and reflected, again, on his own incompetency and failure. This act, however, turned out to be the last chapter of the disgrace. As the Qing political norm went, dismissed officials could sometimes return to office. ${ }^{64}$ Nayancheng was soon reinstated. After a successful mission to the south to investigate two cases involving provincial officials, he was named the head of the Ministry of Rites in $1803 .{ }^{65}$ During the rest of the Jiaqing period and the following Daoguang period (1821-1850), he served mainly as a territorial administrator in provinces and frontiers but also as a ranking official in the central government on occasion. More than once he distinguished himself through significant achievements. In 1813, again in the capacity of the 'Special Imperial Commissioner', he commanded the suppression campaign against the Eight Trigrams Uprising in north China. ${ }^{66}$ In the early 1820 s he settled violent conflicts between the Mongols and Tibetans in Qinghai. Nevertheless, he was never able to climb back to the same height he had reached in 1799 and never had the chance to serve on the Grand Council.67 Moreover, he suffered more

62 JQ 07/02/24, JQCSYD, vol. 7, 46-47.

63 Bartlett thinks that the opposition was mainly against the Grand Council's right of edictdrafting. Bartlett, Monarchs and Ministers, 239-240. But Jiaqing certainly meant to defend his father and himself in a broader sense.

64 JQCSYD, vol. 6, p. 130. Two days later, Jiaqing pardoned him, granting him the title of Vice Commander-in-Chief (Dutong). Ibidem, vol. 6, 132-133. For the practice of reinstating dismissed officials during the Qing, see Guy, Qing Governors and Their Provinces, 160-163.

65 One case involved a provincial official in Jiangxi. The other involved the governor-general of Guangdong and Guangxi for his mishandling of a Triad uprising in Guangdong. In Guangdong he acted as the governor before Jiaqing summoned him back to Beijing.

66 On the Eight Trigrams Uprising in 1813, see Susan Naquin, Millenarian Rebellion in China: The Eight Trigrams Uprising of 1813 (New Haven, 1976). For Nayancheng's role in the suppression campaign, see $245^{-264}$.

67 He was again named to be a probationary member of the Grand Council in mid-1804 (JQCSYD, vol. 9, p. 213), but his subsequent appointment to Shaanxi made him unavailable to serve. Likely, Jiaqing was again pressured to give it up. 
censure and downfalls. In 1806, he was cashiered and exiled to Ili for his mishandling of pirates in Guangdong. In 1816, accused of financial fraud, he was imprisoned and given the death penalty (which was later commuted). A few years before his death, he was again deprived of all his titles and ranks when he was blamed for his alleged mismanagement in Xinjiang following a frontier crisis there. In 1833 he died at home as a commoner.

It was virtually impossible for Jiaqing to foster another leading grand councillor after he failed with Nayancheng. Reluctantly, he had to seek an alternative way to manage the Grand Council. During the rest of his reign, he did not lean on a single grand councillor, but made the Grand Council more oligarchic, letting its four to half a dozen members share the responsibility. In the selection of the grand councillors, military quality and merits were deemphasised, while the jinshi degree was given more weight, which favoured Chinese scholar-officials at the cost of the battlefield-baptised bannermen. In 1805, relatives of high-ranking officials, including grand councillors, lost their easy access to positions as the council's clerks. Instead, experience and capacity became criteria for serving on the council. ${ }^{68}$ With the rise of factional politics in the nineteenth century, it became increasingly difficult for the emperor to follow the precedents of Necin, Fuheng, and Hešen, patronising and delegating his authority to one leading grand councillor. ${ }^{69}$ Meanwhile, the banner aristocrats were losing their advantages in the competition with their nonaristocratic counterparts for the top rungs of the political hierarchy. To a great extent, Nayancheng's downfall in 1800 marks the end of a political tradition of the high Qing period, ushering in an era when the monarch's relationship with his privy aides was considerably different.

68 But the ban on the relatives of the high-ranking officials serving as clerks on the Grand Council was dropped later during the Daoguang period. For an in-depth discussion of the changes to the Grand Council during the Jiaqing period, see Bartlett, Monarchs and Ministers, 239-247.

69 The only grand councillor in the first half of the nineteenth century who enjoyed considerable influence was Mujangga (d. 1856) during the Daoguang period. Yet there were significant differences between him and his eighteenth-century counterparts. With a jinshi degree, Mujangga had been a civil official without any military background. His ascent to become the leading grand councillor was gradual after having served on various agencies in the central government. Most importantly, his power and influence had been seriously checked by the factional struggles of his time. On the factional struggles in the Daoguang period, see James M. Polachek, The Inner Opium War (Cambridge, MA, 1992), especially $205^{-287}$. 